\title{
Morphological and biochemical variations induced by synergy of salicylic acid and zinc in cockscomb
}

\author{
Amna Shoaib ${ }^{1, *}$, Malik Fiaz, Hussain Ferdosi', Muhammad Awais Saleem ${ }^{1}$, \\ Shabnam Javed ${ }^{2}$
}

${ }^{1}$ Faculty of Agricultural Sciences, University of the Punjab, Lahore, Pakistan

${ }^{2}$ Faculty of Chemistry, University of the Punjab, Lahore, Pakistan

\begin{abstract}
Celosia argentea var. cristata is an edible plant mainly cultivated as an ornament for its spectacular flowering and is highly appreciated by horticulturists for its originality, unique appearance of flower and better vase life. Utilisation of plant growth regulator [salicylic acid (SA)] and mineral nutrition [zinc $(\mathrm{Zn})$ ] is a sustainable approach to ameliorate crop health and yield. A field experiment was performed on a randomised complete block design with 12 treatments in 36 blocks to investigate the effectiveness of the combined application of SA (50 ppm and $100 \mathrm{ppm})$ and $\mathrm{Zn}\left(\mathrm{ZnSO}_{4}: 0.5\right.$ ppm, $1.5 \mathrm{ppm}$ and $2.5 \mathrm{ppm}$ ) as well as when each one is applied separately on vegetative, reproductive, physiochemical attributes in C. argentea var. cristata. Results analysed through Tukey's honestly significant difference (HSD) test, biplot and heat map indicated a significantly greater improvement up to 2.5 folds in the growth attributes when plants received foliar application of $100 \mathrm{ppm}$ of SA combined with $2.5 \mathrm{ppm}$ of $\mathrm{Zn}$ as compared to control group. All treatments modified the physiobiochemical responses of plants by lowering catalase (CAT) activity significantly, and enhancing photosynthetic pigments, total protein content and peroxidase (POX) and polyphenol oxidase (PPO) activities as compared to the control group. It was concluded that foliar application of SA $(100 \mathrm{ppm})+\mathrm{Zn}(2.5 \mathrm{ppm})$ at pre-flowering stage could be applied to obtain better growth and flower quality in cockscomb.
\end{abstract}

Keywords: biplot, foliar application, heat map, micronutrient, reproductive indices, synergism

\section{Abbreviations:}

CC, carotenoids; DST, days after seedling transplanting; PCA, principal components analysis; POX, peroxidase; PPO, polyphenol oxidase; SA, salicylic acid; TCC, total chlorophyll content; TPP, total protein content; Zn, zinc.

\section{INTRODUCTION}

Celosia argentea var. cristata (cockscomb) of the family Amaranthaceae is a short-day summer annual, grows in a slightly warm and wet climate, while the plant is heat- and drought-tolerant. It is widespread throughout tropical Africa and Asia and has great economic value as a cut flower around the world because of its attractive shapes, colour, long lasting bloom and better vase life (Zuck, 2015). Phytochemical analysis of different parts of plant revealed the presence of phenolic, flavonoids, tannins, saponins and triterpenoids compounds
(Surse et al., 2014). Moreover, its leaves contained vitamins A and C (NRC, 2006) along with rich source of protein $(4.7 \mathrm{~g})$, carbohydrate $(7.3 \mathrm{~g})$, fibre $(1.8 \mathrm{~g})$, calcium (260 mg) and iron (7.8 mg) per $100 \mathrm{~g}$ serving (Leung et al., 1968). Therefore, its leaf and tender stem are combined with other vegetables in soups, sauces and stews, and moreover its flowers are edible as well (Kolade et al., 2018). Further, the plant is one of versatile components of herbal remedies and has been used in traditional medicine against skin and eyes allergies,

*Corresponding author.

e-mail: amna.iags@pu.edu.pk (Amna Shoaib). 
fever, painful menstruation, liver disorders, headache, cataracts, hypertension, atherosclerosis, osteoporosis and sores, whereas the leaves are effective against cuts, wounds and body swelling, flowers are used to relieve abdominal pain, bleeding from the nose, coughing up blood, urinary infection and vomiting and roots are used against leucorrhoea. Apart from these uses, the different parts of the plants exhibit anti-inflammatory, antihypertension, antioxidant, anti-dysentery, antidiarrhoea, antiviral, antibacterial and anthelmintic actions (Tang et al., 2016; Kolade et al., 2018). So far, the scale of the global market for cut flower is large and ever expanding, whereas, ultra-vivid, deep dark purple-red inflorescence complemented by dark-burgundy foliage of the cockscomb has already gained prominence in the cut-flower industry (Miano et al., 2017). One of the challenges affecting cockscomb production is its growth efficiency during production, which is correlated with stronger stems and better flower density. Unlike other cut-flowers, C. cristata harvested 3-4 weeks after anthesis (flowering) to ensure woodified stem, which is the sole reason for the extension (increase) of the production time. But, the early harvest often results in weaker stem, which causes lodging before or after flowering. Moreover, the weaker stem cannot resist issues associated with the transportation of plant material (Kieft-Pro Seeds, 2010; Zuck, 2015). Therefore, there is need to emphasise on sustainable production methods that can improve growth rate, stem durability and flower density so as to reduce time needed for production that would ultimately result in energyefficient and sustainable practice (Zuck, 2015). Foliar application of growth regulators and micronutrients is one among the feasible and economic efficient methods to boost plant growth efficiency and bioproductivity.

The role of zinc ( $\mathrm{Zn}$ ) as a micronutrient for human and plant nutrition is well established. In plant, $\mathrm{Zn}$ helps in preventing lodging, better growth, biomass production and high quality of cut-flowers (Shaheen et al., 2015; Khan et al., 2018; Bhatt et al., 2020). Zn participates in all major functions of the plant by acting as a co-factor or structural element in 300 catalytic and non-catalytic proteins and pigment biosynthesis (Pérez et al., 2020). It is involved in stomatal regulation, membrane stability, ion balance, cell wall development, metabolism of carbohydrates, lipids and proteins as well as synthesis of phytohormones (auxins, abscisic acid, gibberellins and cytokinins) (Cabot et al., 2019). Being an essential component of several biomolecules, $\mathrm{Zn}$ regulates intracellular signalling pathways and relevant physiological responses in plants by eliminating oxidative stress (Shaheen et al., 2015), by affecting the activity of enzymes, such as catalase (CAT), peroxidase (POX) and polyphenol oxidase (PPO) (Khan et al., 2018). These enzymes are essential for plant growth and development throughout life cycle. For example, the CAT enzyme is integral part of the plant's antioxidative system, contributes in plant defence, aging and senescence (Yang and Poovaiah, 2002). POX enzyme participates in lignification, suberization and crosslinking hydroxyproline-rich proteins (extensins) in the cell wall matrix as well as in control function of redox state in apoplast (Luhová et al., 2006). PPO is nuclearencoded enzyme involved in pigment biosynthesis, acts against stress and catalyses phenol oxidation (Mastuti et al., 2015). Soil Zn application has been documented already and it stated that $\mathrm{Zn}$ application has improved the growth and quality of oriental Lilly by maintaining the activity of antioxidant enzymes and enhancing membrane stability (CAT and POX) (Shaheen et al., 2015). Kolade et al. (2018) findings indicated that $\mathrm{Zn}$ fertilisation $\left(50 \mathrm{mg} \cdot \mathrm{kg}^{-1}\right)$ in C. argentea improved the plant performance by increasing nitrogen, potassium and magnesium concentrations, thus significantly improved its dietary benefits for human. Awan et al. (2019) and Shoaib et al. (2020) findings revealed that basal $\mathrm{Zn}$ improved the photosynthetic pigment, activity of antioxidants (POX, CAT and PPO) in tomato and mung bean, respectively and alleviated the biotic stress in the plants. However, in many studies, the foliar application of $\mathrm{Zn}$ has shown 6 to 20 times more beneficial than the basal application, and foliar $\mathrm{Zn}$ has proved to be an efficient and economic method to significantly increase crop growth and yield. Foliar $\mathrm{ZnSO}_{4}$ improved length and width of leaf, weight and diameter of corm in gladiolus (Hembrom et al., 2015), length of rachis and duration of flowering in gladiolus (Singh et al., 2015), plant and flower attributes in marigold (Shah et al., 2016), bud initiation, bud diameter and flower weight in African marigold (Singh et al., 2018).

Apart from Zn, salicylic acid (SA) contributes a lot in the growth, by acting as an endogenous growth regulator of phenolic nature produced by root cells, by modifying plant performance by modulating key metabolic and physiological processes (Dempsey et al., 2017) that can't be overlooked. It has been described that SA plays an important role in photosynthesis performance by increasing the stomatal conductance levels, transpiration rates and enzyme activity related to $\mathrm{CO}_{2}$ uptake at the chloroplast level (Janda et al., 2014). Increase in the rate of carbohydrate metabolism of plants lead to more efficient metabolic responses through increased content of soluble sugars and protein (Hasanuzzaman et al., 2017). SA regulates ion uptake by roots, aids in synthesis of kinase protein, which regulate cell division and differentiation, initiate root elongation, stimulate leaves in young shoot and bud behaviours. Hence, it can be concluded that SA positively affects the growth rate and plant productivity and induce flowering in various plant species (Dempsey et al., 2017). Further, SA strengthens vascular cells, delay senescence by regulating the plant water and activity of antioxidants (CAT, POX, etc.) against oxidants generated during senesces (Alaey et al., 2011; Khan et al., 2020). However, the plant responses to exogenous SA vary with species, SA concentrations and mode of application (Miura and Tada, 2014). Pacheco et al. (2013) reported the high flavonoid content and higher biomass production in marigold plants 
after the consecutive 3 days foliar application of SA (60-140 ppm) before the reproductive stage. Abbas and Ibrahim (2014) suggested spraying of $50 \mathrm{ppm}$ of SA for increasing the growth, yield, and oil ratio indices in black bean. SA (100 ppm) positively and significantly influences number of leaves, spikes and florets spike by accelerating the cell divisions in the apical portion of the sprouts in gladiolus (Pal and Kumar, 2015). The highest rate of vegetative, reproductive and nutrient attributes was obtained due to spraying of $200 \mathrm{ppm} \mathrm{SA}$ in thorn apple (Al-Mohammadi and Al-Rawim, 2016) and $100 \mathrm{ppm}$ in Zinnia (Zeb et al., 2017). Marigold received spray of SA ( $80 \mathrm{ppm}$ and $120 \mathrm{ppm}$ ) on aerial parts after 60 days of sowing and exhibited maximum number of leaves, plant height, number of inflorescence, stem diameter, fresh and dry weight of flowers in marigold (Basit et al., 2018). Choudhary et al. (2016) studies revealed that synergism of foliar spraying with $\mathrm{Zn}(1.0 \%)$ and SA $\left(1.0 \mathrm{Mm} \cdot \mathrm{L}^{-1}\right)$ positively increased the growth and flowering parameters in marigold. Ahmad et al. (2018) recommend SA (2 mM) application as foliar at 5 th week to achieve the best growth and production of tuberose flowers and bulbs.

Only few literatures are available on physiological responses in ornamental plants after $\mathrm{Zn}$ or SA application, but foliar SA and $\mathrm{Zn}$ could be used as sustainable approach to ameliorate growth rate, physiological responses and productivity in C. argentea var. cristata. Modulation in plant responses to $\mathrm{Zn}$ or SA application can be analysed adequately and quickly through cluster and correlation analyses. The biplot based on principal component analysis (PCA) and heat map (hierarchical clustering) are statistical techniques frequently utilised to obtain more reliable information for assessing potential associations between phenotypic components and to identify the leading component along with identification of potential treatment/s (Han et al., 2019; Siddique et al., 2020). In this regard, TahjibUl-Arif et al. (2018) findings suggested that SA is an important activator of antioxidant capacity in plants under saline conditions, which is found by using PCA and heat map visualisation. Likewise, Matysiak (2020) analysed 12 morpho-growth traits in wheat after application of acetylsalicylic acid and revealed usefulness of PCA application in assessing effect of concentrations and timing of acetylsalicyclic acid on the investigated attributes. Shariatipour et al. (2020) utilised heat map and biplot analyses which revealed positive relationship between $\mathrm{Zn}$ accumulations in the grains of different genotype of wheat after foliar application of $\mathrm{Zn}$. Therefore, biplot and heat map can be used as potential methods to comprehensibly analyse data to screen out excellent treatment and trait from large set of the treatment/data. The objective of this study was to evaluate the effect of foliar application of different concentrations of $\mathrm{Zn}(0.5 \mathrm{ppm}, 1.5 \mathrm{ppm}$ and $2.0 \mathrm{ppm})$ and SA (50 ppm and $100 \mathrm{ppm}$ ) separately as well as in combination in improving growth characters, flower quality and associated physiological attributes in $C$. argentea var. cristata. Finally, the data on the investigated attributes were analysed through biplotbased PCA and heat map to identify best treatment and the response of phenotypic traits to the treatment/s.

\section{MATERIALS AND METHODS}

\section{Experimental design and site description}

The experiment of 12 treatments was conducted in a randomised complete block design having factorial arrangement with replications of three times per treatment. One treatment consisted of 15 plants, as there were 5 plants in each replicate. In the first factor, different concentrations of $\mathrm{Zn}$ were applied, while in second factor different concentrations of SA were given and further combinations of $\mathrm{Zn}$ and SA were applied under the third factor (Table 1).

Field experiment was carried out at the experimental area of $850 \mathrm{sq} . \mathrm{ft}$ at Institute of Agricultural Sciences, University of the Punjab, Lahore $\left(31^{\circ} 32^{\prime} \mathrm{N}\right.$ latitude and $74^{\circ} 20^{\prime}$ E longitudes), during June-October, 2019. The average temperature during this period was $38{ }^{\circ} \mathrm{C}$, relative humidity was $55 \%$ and average rainfall was $48.2 \mathrm{~mm}$.

Total experimental area was $7,600 \mathrm{~cm}^{2}$. To remove hard pans and other plants material, the land was mechanically tilled about $10 \mathrm{~cm}$ deep with cultivar and left opened for 3 days for sun solarisation. After ploughing the field, soil was fumigated with $20 \%$ formalin solution. Cotton plugs were dipped in a formalin solution and then placed at different positions in soil to disinfect soil. After this, the soil was covered with polythene sheet for 3 weeks. After 21 days, the polythene sheet was removed and soil was mixed well. Then it was left open to remove the formalin residues. Before dividing the field into sub-plots for replicates, the field was irrigated manually. Total experimental area was divided into 36 plots each measuring $120 \mathrm{~cm} \times 120 \mathrm{~cm} \cdot$ plot $^{-1}$. Farm yard manure $(\mathrm{FYM})$ was mixed manually at dose of $1 \mathrm{~kg} \cdot$ plot $^{-1}$. Experimental unit was irrigated as per required at all critical stages of crop. Weeding and hoeing operations were completed according to needs.

\section{Conduction of the experiment}

Healthy seeds of $C$. argentea var. cristata were surface sterilised with $1 \%$ sodium hypochlorite, were dried by placing them on filter paper and were sown on a tray using coconut husk and peat moss of equal percentage

Table 1. Layout of the experiment.

\begin{tabular}{lcccc}
\hline Factors & $\begin{array}{c}\mathrm{Zn} \\
(0.0 \mathrm{ppm})\end{array}$ & $\begin{array}{c}\mathrm{Zn} \\
(0.5 \mathrm{ppm})\end{array}$ & $\begin{array}{c}\mathrm{Zn} \\
(1.5 \mathrm{ppm})\end{array}$ & $\begin{array}{c}\mathrm{Zn} \\
(2.0 \mathrm{ppm})\end{array}$ \\
\hline SA (0.0 ppm) & $\mathrm{T}_{1}$ & $\mathrm{~T}_{2}$ & $\mathrm{~T}_{3}$ & $\mathrm{~T}_{4}$ \\
SA (50 ppm) & $\mathrm{T}_{5}$ & $\mathrm{~T}_{6}$ & $\mathrm{~T}_{7}$ & $\mathrm{~T}_{8}$ \\
SA (100 ppm) & $\mathrm{T}_{9}$ & $\mathrm{~T}_{10}$ & $\mathrm{~T}_{11}$ & $\mathrm{~T}_{12}$ \\
\hline
\end{tabular}

SA, salicylic acid; Zn, zinc. 
as a germination substrate. After 25 days, seedlings were transplanted in small pots, and when seedlings reached the height of $7.62 \mathrm{~cm}$, they were transplanted in fields by maintaining the distance of $30.48 \mathrm{~cm}$ from plant to plant and then field was irrigated. SA, Zn and their combinations were sprayed $(150 \mathrm{~mL})$ uniformly on the foliage at $32 \mathrm{nd}$ day and at 58th days after seedling transplanting (DST).

Concentration of $0.5 \mathrm{ppm}, 1.5 \mathrm{ppm}$ and $2.0 \mathrm{ppm}$ were prepared by dissolving $0.015 \mathrm{~g}, 0.045 \mathrm{~g}$ and $0.06 \mathrm{~g}$ of $\mathrm{ZnSO}_{4}$ (Merck) in $3 \mathrm{~L}$ of distilled water, respectively. SA (2-hydroxybenzoic acid, Merck) was initially dissolved in $1,000 \mu \mathrm{L}$ dimethyl sulfoxide to make a volume up to $100 \mathrm{~mL}$, and later $50 \mathrm{ppm}$ and $100 \mathrm{ppm}$ concentration were prepared from the standard solution.

\section{Characteristics evaluated}

Biochemical attributes like total chlorophyll contents (TCCs), carotenoids (CC), total protein contents, CAT, POX and PPO activities were evaluated following the protocols of Nafisa et al. (2020) from the triplicate samples of leaves collected from each replicates at 60 DST.

\section{Photosynthetic pigment}

TCC and carotenoid contents were determined in ethanolic mixture of leaf extract, obtained after homogenising 0.1 leaf sample in $80 \%$ ethanol. Absorbance of supernatant was determined at $470 \mathrm{~nm}$, $645 \mathrm{~nm}$ and $663 \mathrm{~nm}$ by UV spectrophotometer.

\section{Total protein content and enzymes activity assays}

For the estimation of total protein content, leaf sample $(0.5 \mathrm{~g})$ was crushed in phosphate buffer $(0.1 \mathrm{M}, \mathrm{pH}$ $7.5)$ in pre-chilled pestle and mortar in liquid nitrogen followed by centrifugation at 3,000 rpm for $10 \mathrm{~min}$ and addition of $1 \mathrm{~mL}$ of reagent $\mathrm{C}$ [prepared by mixing reagent $\mathrm{A}\left(0.2 \% \mathrm{NaOH}\right.$ and $\left.2 \% \mathrm{Na}_{2} \mathrm{CO}_{3}\right)$ and reagent $\mathrm{B}$ $\left(0.5 \% \mathrm{CuSO}_{4}\right.$ in $1 \%$ of $\left.\mathrm{KNaC}_{4} \mathrm{H}_{4} \mathrm{O}_{6} \cdot 4 \mathrm{H}_{2} \mathrm{O}\right)$ in $50: 1$ ratio]. The mixture was shaken for $10 \mathrm{~min}$, then $0.1 \mathrm{~mL}$ Folin phenol reagent was added and finally incubated at room temperature for $30 \mathrm{~min}$. The total protein content was estimated at $650 \mathrm{~nm}$ by using the standard curve of Bovine serum albumin.

To assess the activity of antioxidant enzymes, $0.1 \mathrm{~g}$ of leaf was ground in $0.1 \mathrm{M}$ phosphate buffer, centrifuged at 3,000 rpm for $10 \mathrm{~min}$, and supernatant was used for enzymes activities assays. For CAT, a mixture containing $50 \mathrm{mM}$ phosphate buffer $(\mathrm{pH} 7.0), 0.3 \% \mathrm{H}_{2} \mathrm{O}_{2}$ and $100 \mu \mathrm{L}$ enzyme extract was assessed for absorbance at $240 \mathrm{~nm}$ at the intervals of $30 \mathrm{~s}$. POX activity was determined in the reaction mixture contained $2 \mathrm{~mL}$ of $0.1 \mathrm{M}$ phosphate buffer ( $\mathrm{pH} 6.8$ ), $1 \mathrm{~mL}$ of $0.01 \mathrm{M}$ pyrogallol, $1 \mathrm{~mL}$ of $0.05 \mathrm{M} \mathrm{H}_{2} \mathrm{O}_{2}$ and $0.5 \mathrm{~mL}$ of enzyme extract. The solution was incubated for $5 \mathrm{~min}$ at $25^{\circ} \mathrm{C}$ after which the reaction was terminated with addition of $1 \mathrm{~mL}$ of $2.5 \mathrm{~N} \mathrm{H}_{2} \mathrm{SO}_{4}$. The amount of purpurogallin formed was determined by measuring the absorbance at $420 \mathrm{~nm}$. For PPO, the reaction mixture consisted $100 \mu \mathrm{L}$ enzyme extract and $1.5 \mathrm{~mL}$ of $0.1 \mathrm{M}$ sodium phosphate buffer (pH 7.0), the reaction started when $200 \mu \mathrm{L}$ of 0.01 $\mathrm{M}$ catechol was added. The changes in the absorbance were recorded at $30 \mathrm{~s}$ intervals for $3 \mathrm{~min}$ at $495 \mathrm{~nm}$.

\section{Growth and reproductive indices}

Reproductive indices including number of buds per plant and fresh weight of flower were recorded at 65 and 105 DST, respectively, while growth indices like stem diameter, length, fresh and dry weight of root and shoot were taken at $120 \mathrm{DST}$.

\section{Statistical and multivariate analysis}

The statistical analyses were conducted using statistical software Statistics 8.1 at $p<0.05$ based on the proposed design. Two-way factorial ANOVA was used to test the main and interaction effects of the corresponding factors and Turkey's HSD test differentiated mean values of all treatments with respect to control. Principal components analysis (PCA) and heat maps were built to summarise the variability of the treatments, and to determine the association among the measured traits.

\section{RESULTS}

\section{Vegetative growth indices}

Table 1 shows various treatments, where three different concentration of $\mathrm{Zn}$ and two different concentrations of SA were applied on the plants separately and in combination. A statistically significant difference $(p<0.05)$ in stem diameter as well as in all shoot-related measurements was recorded in $\mathrm{T}_{2}-\mathrm{T}_{4}(\mathrm{Zn}: 0.5 \mathrm{ppm}$, $1.5 \mathrm{ppm}$ and $2.5 \mathrm{ppm}), \mathrm{T}_{9}(\mathrm{SA}: 100 \mathrm{ppm})$ and their combinations in $\mathrm{T}_{10}-\mathrm{T}_{12}(\mathrm{SA}+\mathrm{Zn})$ with respect to control $\left(\mathrm{T}_{1}\right)$. Lower concentration of $\mathrm{SA}$ either alone $\left(\mathrm{T}_{5}: 50 \mathrm{ppm}\right)$ or combined with $\mathrm{Zn}\left(\mathrm{T}_{6}-\mathrm{T}_{8}\right)$ did not show any significant effect on the investigated traits (Table 2). The greatest improvement of $60-281 \%$ was recorded in $\mathrm{T}_{12}(100 \mathrm{ppm} \mathrm{SA}+2.5 \mathrm{ppm} \mathrm{Zn})$ followed by $\mathrm{T}_{11}(100 \mathrm{ppm} \mathrm{SA}+1.5 \mathrm{ppm} \mathrm{Zn})$. Other treatments including, $\mathrm{T}_{2}-\mathrm{T}_{4}(0.5-2.5 \mathrm{ppm}), \mathrm{T}_{9}(\mathrm{SA}: 100 \mathrm{ppm})$ and $\mathrm{T}_{10}$ (Zn: $0.5 \mathrm{ppm}+\mathrm{SA}: 100 \mathrm{ppm}$ ), significantly improved the stem diameter by $50-70 \%$, length, fresh and dry weight of shoots are improved by $30-40 \%, 70-100 \%$ and $140-160 \%$, respectively with respect to control. Moreover, average letters in rows revealed that $1.5 \mathrm{ppm}$ and $2.5 \mathrm{ppm}$ of $\mathrm{Zn}$ resulted in higher shoot-related attributes than $0.5 \mathrm{ppm}$. Likewise, average letters in a column exhibited statistically greater effect due to higher SA level (100 ppm) than lower level (50 ppm) (Table 2).

Root lengths and fresh weights were increased significantly by $30-40 \%$ and $50-70 \%$, respectively in $\mathrm{T}_{12}$ followed by $\mathrm{T}_{11}$ as compared with control. However, for the treatments provided with $1.5 \mathrm{ppm}$ and $2.5 \mathrm{ppm}$ of $\mathrm{Zn}$, higher level of SA and their combinations were found optimum for significantly improving the dry biomass by $50-100 \%$. Furthermore, value of uppercase alphabets in rows and column revealed that $\mathrm{Zn}$ and SA 
Table 2. Effect of foliar application of SA and Znon the vegetative and reproductive growth indices in Celosia argentea var. cristata plants.

\begin{tabular}{|c|c|c|c|c|c|c|c|}
\hline \multirow[t]{2}{*}{ DST } & \multirow[t]{2}{*}{ Parameters } & \multirow[t]{2}{*}{ SA level (ppm) } & \multicolumn{5}{|c|}{ Zn level (ppm) } \\
\hline & & & 0 & 0.5 & 1.5 & 2.5 & Mean \\
\hline \multirow{28}{*}{$\begin{array}{l}\hat{⿹} \\
\text { D } \\
\text { 오 }\end{array}$} & \multirow{4}{*}{ Stem diameter (mm) } & 0 & $23 \mathrm{e}$ & $35 \mathrm{~b}-\mathrm{d}$ & $38 \mathrm{a}-\mathrm{c}$ & $31 \mathrm{~b}-\mathrm{d}$ & $33 \mathrm{~B}$ \\
\hline & & 50 & $30 \mathrm{c}-\mathrm{e}$ & $26 \mathrm{de}$ & $28 \mathrm{de}$ & $31 \mathrm{de}$ & $29 \mathrm{C}$ \\
\hline & & 100 & $34 b-d$ & $35 b-d$ & $42 \mathrm{ab}$ & $47 \mathrm{a}$ & $40 \mathrm{~A}$ \\
\hline & & Mean & $29 \mathrm{C}$ & $32 \mathrm{BC}$ & $36 \mathrm{AB}$ & $37 \mathrm{~A}$ & \\
\hline & \multirow{4}{*}{ Shoot length (cm) } & 0 & $29 \mathrm{c}$ & $40 \mathrm{ab}$ & $43 \mathrm{ab}$ & $39 \mathrm{ab}$ & $37 \mathrm{~B}$ \\
\hline & & 50 & $35 \mathrm{bc}$ & $35 \mathrm{bc}$ & $36 \mathrm{bc}$ & $37 \mathrm{bc}$ & $36 \mathrm{AB}$ \\
\hline & & 100 & $38 \mathrm{bc}$ & $41 \mathrm{ab}$ & $45 \mathrm{a}$ & $46 \mathrm{a}$ & $43 \mathrm{~A}$ \\
\hline & & Mean & $34 \mathrm{~B}$ & $39 \mathrm{~A}$ & $41 \mathrm{~A}$ & $42 \mathrm{~A}$ & \\
\hline & \multirow{4}{*}{ Shoot fresh weight (g) } & 0 & $458 \mathrm{~d}$ & $883 \mathrm{ab}$ & $936 \mathrm{ab}$ & $803 \mathrm{bc}$ & $770 \mathrm{~B}$ \\
\hline & & 50 & $673 \mathrm{~d}$ & $536 \mathrm{~d}$ & $563 \mathrm{~d}$ & $646 \mathrm{~cd}$ & $576 \mathrm{C}$ \\
\hline & & 100 & $899 \mathrm{ab}$ & $770 \mathrm{bc}$ & $897 \mathrm{ab}$ & $1023 \mathrm{a}$ & $910 \mathrm{~A}$ \\
\hline & & Mean & $638 \mathrm{C}$ & $730 \mathrm{~B}$ & $815 \mathrm{AB}$ & $824 \mathrm{~A}$ & \\
\hline & \multirow{4}{*}{ Shoot dry weight (g) } & 0 & $186 \mathrm{f}$ & $433 \mathrm{~cd}$ & $475 \mathrm{bc}$ & $430 \mathrm{~cd}$ & $381 \mathrm{~B}$ \\
\hline & & 50 & $293 \mathrm{ef}$ & 296 e & 320 e & $333 \mathrm{de}$ & $311 \mathrm{C}$ \\
\hline & & 100 & $430 \mathrm{~cd}$ & $453 \mathrm{c}$ & $566 \mathrm{~b}$ & $687 \mathrm{a}$ & $534 \mathrm{~A}$ \\
\hline & & Mean & $304 \mathrm{C}$ & $394 \mathrm{~B}$ & $453 \mathrm{~A}$ & $483 \mathrm{~A}$ & \\
\hline & \multirow{4}{*}{ Root length (cm) } & 0 & $19 \mathrm{c}$ & $25 \mathrm{a}-\mathrm{c}$ & $26 \mathrm{a}-\mathrm{c}$ & $24 \mathrm{a}-\mathrm{c}$ & $23 \mathrm{~B}$ \\
\hline & & 50 & $21 \mathrm{bc}$ & $21 \mathrm{bc}$ & $22 \mathrm{a}-\mathrm{c}$ & $22 \mathrm{a}-\mathrm{c}$ & $21 \mathrm{~B}$ \\
\hline & & 100 & $25 \mathrm{a}-\mathrm{c}$ & $26 \mathrm{a}-\mathrm{c}$ & $27 \mathrm{ab}$ & $30 \mathrm{a}$ & $27 \mathrm{~A}$ \\
\hline & & Mean & $22 \mathrm{~A}$ & $24 \mathrm{~A}$ & $25 \mathrm{~A}$ & $25 \mathrm{~A}$ & \\
\hline & \multirow{4}{*}{ Root fresh weight (g) } & 0 & $57 \mathrm{c}$ & $77 \mathrm{a}-\mathrm{c}$ & $82 \mathrm{a}-\mathrm{c}$ & $75 a-c$ & $72 \mathrm{AB}$ \\
\hline & & 50 & $62 \mathrm{bc}$ & $64 \mathrm{bc}$ & $66 \mathrm{a}-\mathrm{c}$ & $70 a-c$ & $66 \mathrm{~B}$ \\
\hline & & 100 & $70 \mathrm{a}-\mathrm{c}$ & $70 \mathrm{a}-\mathrm{c}$ & $85 \mathrm{ab}$ & $93 \mathrm{a}$ & $81 \mathrm{~A}$ \\
\hline & & Mean & $62 \mathrm{~B}$ & $72 \mathrm{AB}$ & $78 \mathrm{~A}$ & $79 \mathrm{~A}$ & \\
\hline & & 0 & $37 \mathrm{~d}$ & $54 \mathrm{~b}-\mathrm{d}$ & $59 \mathrm{a}-\mathrm{c}$ & $56 \mathrm{a}-\mathrm{c}$ & $52 \mathrm{~B}$ \\
\hline & & 50 & $48 \mathrm{~cd}$ & $46 \mathrm{~cd}$ & $47 \mathrm{~cd}$ & $50 \mathrm{~cd}$ & $48 \mathrm{~B}$ \\
\hline & Root dry weight (g) & 100 & $59 \mathrm{a}-\mathrm{c}$ & $60 \mathrm{a}-\mathrm{c}$ & $69 \mathrm{ab}$ & $74 \mathrm{a}$ & $65 \mathrm{~A}$ \\
\hline & & Mean & $48 \mathrm{~B}$ & $53 \mathrm{AB}$ & $59 \mathrm{~A}$ & $58 \mathrm{~A}$ & \\
\hline \multirow{4}{*}{$\begin{array}{l}\sqrt{n} \\
\hat{n} \\
\ddot{b}\end{array}$} & \multirow{4}{*}{ Number of buds $\cdot$ plant $^{-1}$} & 0 & $47 \mathrm{e}$ & $61 \mathrm{~b}-\mathrm{e}$ & $68 \mathrm{bc}$ & $64 \mathrm{~b}-\mathrm{d}$ & $60 \mathrm{~B}$ \\
\hline & & 50 & $54 \mathrm{c}-\mathrm{e}$ & $52 \mathrm{de}$ & $55 \mathrm{c}-\mathrm{e}$ & $57 \mathrm{c}-\mathrm{e}$ & $54 \mathrm{~B}$ \\
\hline & & 100 & $65 \mathrm{~b}-\mathrm{d}$ & $60 \mathrm{~b}-\mathrm{e}$ & $73 \mathrm{ab}$ & $80 \mathrm{a}$ & $70 \mathrm{~A}$ \\
\hline & & Mean & $55 \mathrm{~B}$ & $58 \mathrm{~B}$ & $65 \mathrm{~A}$ & $68 \mathrm{~A}$ & \\
\hline \multirow{4}{*}{ 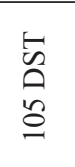 } & \multirow{4}{*}{ Flower weight (g) } & 0 & $5.83 \mathrm{f}$ & $8.33 \mathrm{c}-\mathrm{e}$ & $9.6 \mathrm{bc}$ & $9.3 \mathrm{~b}-\mathrm{d}$ & $8.25 \mathrm{~B}$ \\
\hline & & 50 & $7.40 \mathrm{ef}$ & $7.41 \mathrm{~d}-\mathrm{f}$ & $7.46 \mathrm{~d}-\mathrm{f}$ & $7.83 \mathrm{c}-\mathrm{f}$ & $7.52 \mathrm{C}$ \\
\hline & & 100 & $8.56 \mathrm{c}-\mathrm{e}$ & $8.51 \mathrm{c}-\mathrm{e}$ & $10.50 \mathrm{~b}$ & $12.96 \mathrm{a}$ & $10.12 \mathrm{~A}$ \\
\hline & & Mean & $7.25 \mathrm{C}$ & $8.06 \mathrm{C}$ & $9.18 \mathrm{~B}$ & $10.22 \mathrm{~A}$ & \\
\hline
\end{tabular}

Values with same lower case (rows) and upper case (rows and column) show insignificant difference $(p \leq 0.05)$ as determined by Tukey's test. DST, days after seedling transplanting; SA, salicylic acid; Zn, zinc.

were optimum for root-related attributes only at their higher levels (Table 2).

\section{Reproductive growth indices}

Just like vegetative growth assays, mean effect of SA and $\mathrm{Zn}$ significantly increased reproductive growth indices at their higher levels. Moreover, interaction of $\mathrm{SA}+\mathrm{Zn}$ levels boosted the said attributes at higher level of SA (100 ppm) and Zn (2.5 ppm) as well. Lower level of SA (50 ppm) either used separately or with Zn did not improve reproductive indices significantly. Hence, number of buds per plant was significantly less (47) in control, while the highest number (83) was recorded in the plants treated with SA $(100 \mathrm{ppm})+\mathrm{Zn}(2.5 \mathrm{ppm})$ followed by 72 buds per plant with SA $(100 \mathrm{ppm})+\mathrm{Zn}$ (1.5 ppm). Other treatments that include higher levels of $\mathrm{Zn}$ (1.5 and $2.5 \mathrm{ppm}), \mathrm{SA}(100 \mathrm{ppm})$ or their combinations exhibited less significant effect in improving number of buds $(40 \%)$ with respect to the control treatment (Table 2).

Significantly greater flower weight was recorded in $T_{12}$ followed by $T_{11}$, which were provided with combined application of higher levels of SA $+\mathrm{Zn}$, and it is observed that flower weight increased significantly by $123 \%$ and $80 \%$, respectively over control (5.83 g). Application of $1.5,2.5$ and $0.5 \mathrm{ppm}$ of $\mathrm{Zn}$ improved the flower weight significantly by 65,40 and $43 \%$, respectively, and these treatments were statistically similar. Likewise, the 
application of SA alone (100 ppm) and in combination with $0.5 \mathrm{ppm}$ of $\mathrm{Zn}$ displayed statistically similar increase of $50 \%$ in flower weight with respect to control (Table 2).

\section{Biochemical indices}

In the control treatments, the TCC and $\mathrm{CC}$ of fresh weight of leaf were 2.52 and $0.44 \mathrm{mg} \cdot \mathrm{g}^{-1}$, respectively. These attributes were significantly improved by $30-50 \%$ in the all treatments that are provided with $\mathrm{Zn}$ $(0.5,1.5$ and $2.5 \mathrm{ppm})$ and at higher level of SA (100 ppm SA) either separately or in combination. However, lower level of SA (50 ppm) and its combination with $\mathrm{Zn}$ levels did not affect the said attributes significantly as compared to the control (Figure 1A and B). Total protein content, as well as activities of POX and PPO were generally enhanced significantly by $20-30 \%$ due to applications of different concentrations of $\mathrm{Zn}$ or SA applied alone or simultaneously as compared to control $\left(0.43 \mathrm{mg} \cdot \mathrm{g}^{-1}, 50.14\right.$ and $23.59 \mathrm{U} \cdot \mathrm{min}^{-1} \cdot \mathrm{mg}^{-1}$ protein, respectively) (Figure 1C, E and F). The activity of CAT was significantly greater $\left(6.67 \mathrm{U} \cdot \mathrm{min}^{-1} \cdot \mathrm{mg}^{-1}\right.$ protein $)$ in leaves of control treatments as compared to rest of the treatments. The influence of foliar application of $\mathrm{Zn}$ or SA alone or in synergism significantly reduced CAT activity by $41-65 \%$. The highest reduction of $65 \%$ in the CAT activity was recorded in $\mathrm{T}_{3}$ and $\mathrm{T}_{12}$. The other $\mathrm{Zn}$ (0.5 and $2.5 \mathrm{ppm})$ and SA (100 ppm) levels, when applied alone and in bilateral combination statistically presented similar or same reduction of $51-55 \%$ in
CAT activity as compared to control. Low dose of SA (50 ppm) also showed significant reduction of $43 \%$ when applied separately, while reduction in the CAT activity increased from $43 \%$ to $48 \%$ when SA (50 ppm) was given with different concentrations of $\mathrm{Zn}$ as compared to control (Figure 1D).

\section{Biplot and heatmap analysis}

The PCA score-plot accounted for $89.93 \%$ of the total variance and shows a degree of separation among the treatments. The placement of $\mathrm{T}_{1}$ along the negative values of PC1 was due to low measurements of the remaining variables of growth, reproduction and physiology. However, all variables increased with foliar application of SA and $\mathrm{Zn}$ as indicated by placement of the remaining treatments. $\mathrm{T}_{5}-\mathrm{T}_{8}$, placement along the $\mathrm{PC} 2$ revealed a lower value of all variables as compared to other treatments. Moreover, $\mathrm{T}_{2}-\mathrm{T}_{4}, \mathrm{~T}_{9}$ and $\mathrm{T}_{10}$ exhibited intermediate to high values all the traits along the PC1 component. However, the placement of $\mathrm{T}_{11}$ and $\mathrm{T}_{12}$ just opposite to $\mathrm{T}_{1}$ and along the positive side of $\mathrm{PC} 1$ exhibited the maximum values of the attributes. The location of morpho-physiological traits on the positive side of $\mathrm{PCl}$ indicated their positive association with each other and with the treatments $\left(\mathrm{T}_{2}-\mathrm{T}_{12}\right)$, while CAT exhibited rather different trend. CAT activity was maximum in $\mathrm{T}_{1}$, and minimum in other treatments (Figure 2).

The aggregated data heat-map analysis identified two main clusters. Cluster I corresponding to all treatments
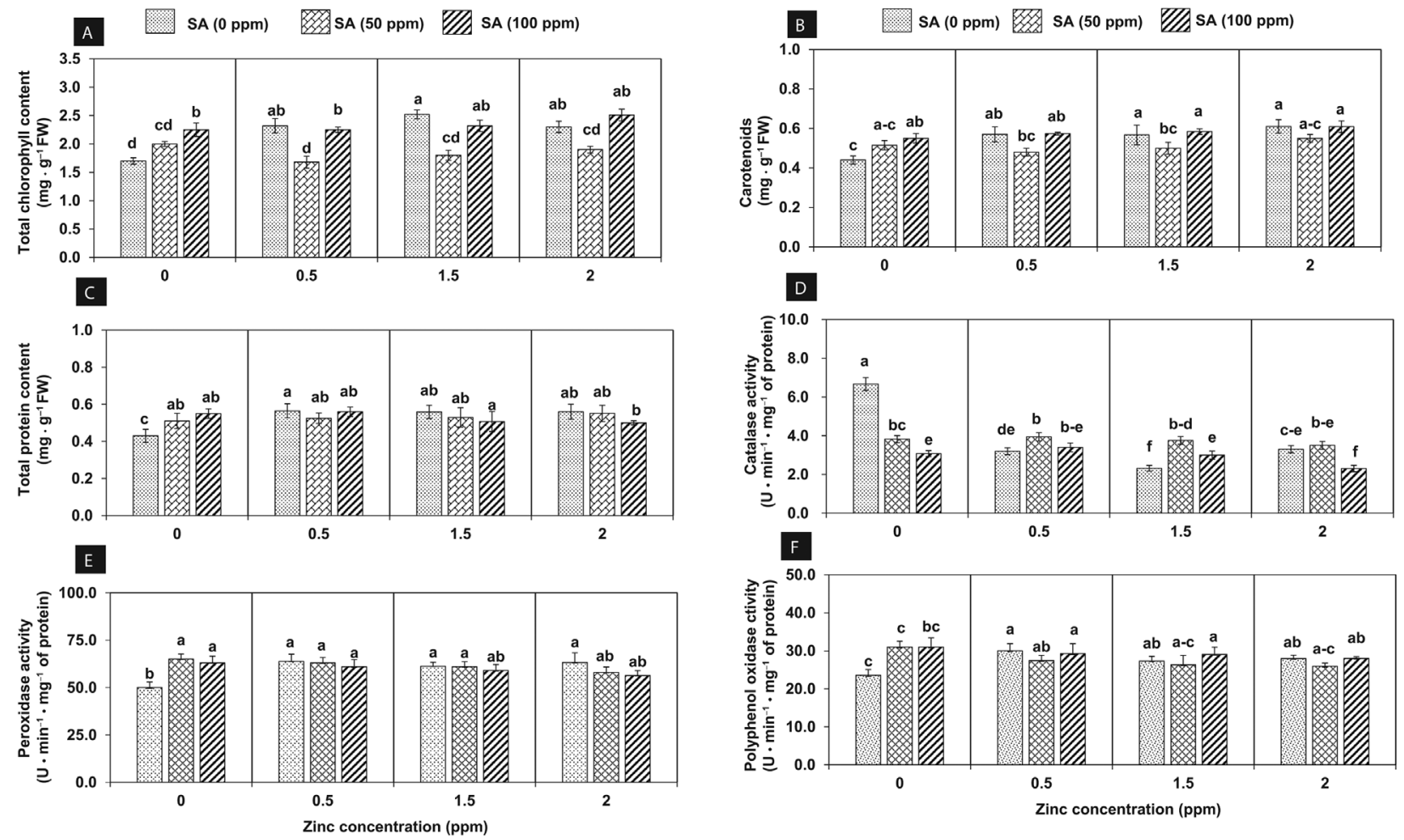

Figure 1. (A-F) Effects of foliar application SA and Zn and the physiological attributes in Celosia argentea var. cristata at 60th day after seedling transplanting. Vertical bars show standard errors of means of three replicates letters indicate significant differences $(p<0.05)$ according to Turkey's test. SA, salicylic acid; Zn, zinc. 


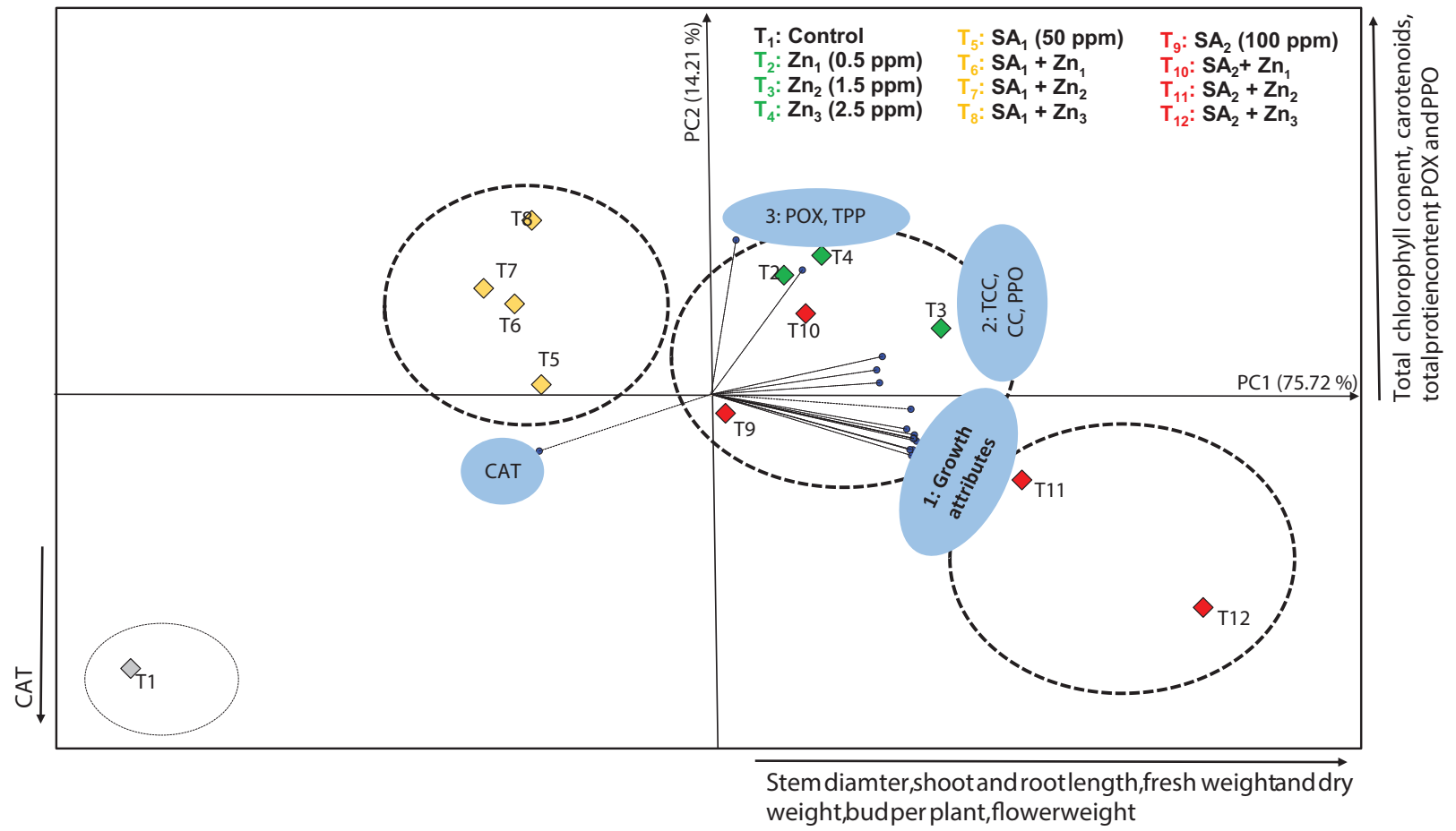

Figure 2. PCA due to effect of foliar application of SA and $\mathrm{Zn}$ on morpho-physiological attributes in Celosia argentea var. cristata. CAT, catalase; CC, carotenoids; PCA, principal components analysis; POX, peroxidase; PPO, polyphenol oxidase; SA, salicylic acid; TCC, total chlorophyll content; TPC, total protein content; Zn, zinc.

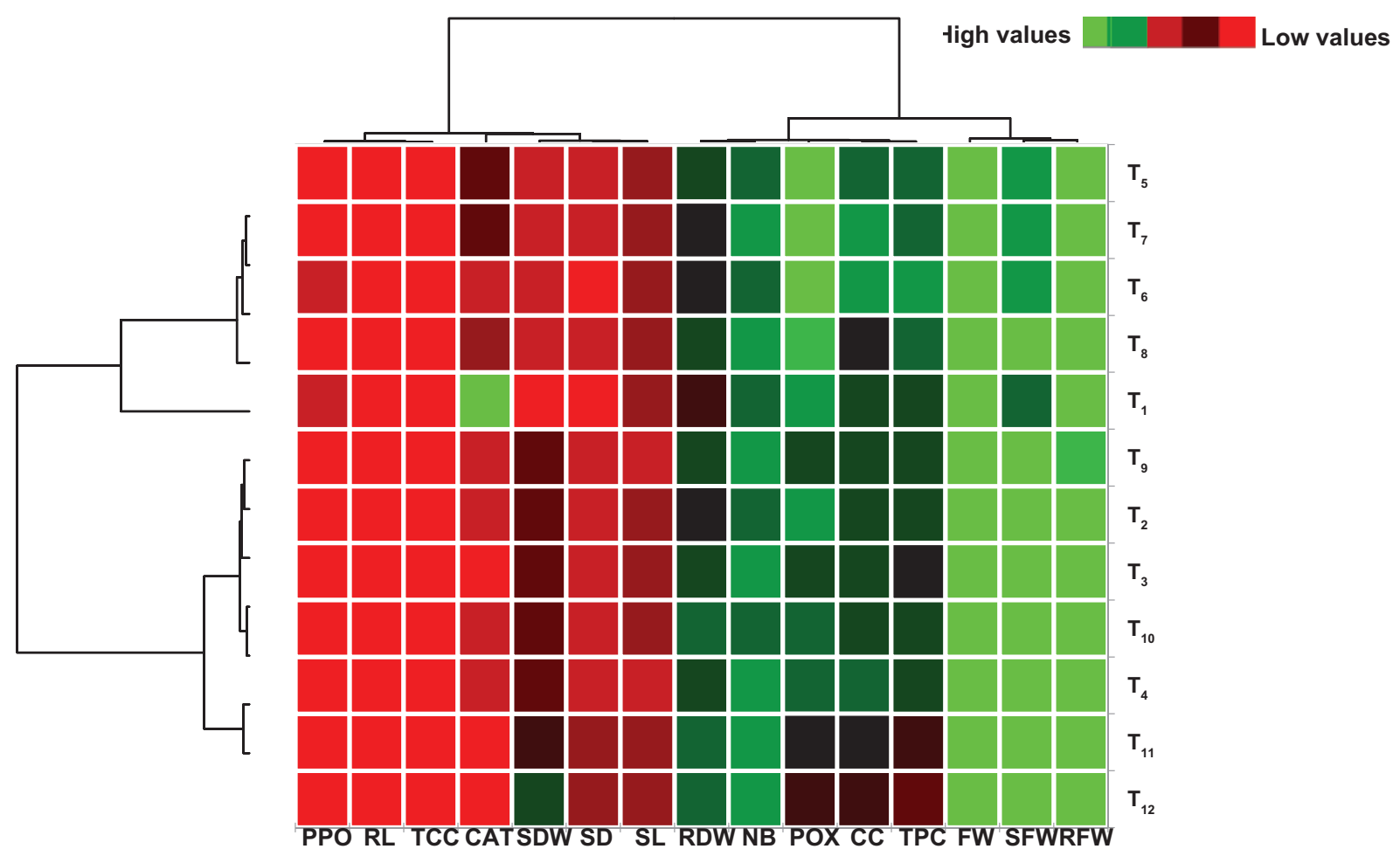

Figure 3. Heat map visualisation of variables and the treatments due to effect of foliar application of SA and Zn on Celosia argentea var. cristata. CAT, catalase; CC, carotenoids; FW, flower weight; NB, number of buds/plant; POX, peroxidase; PPO, polyphenol oxidase; RDW, root dry weight; RFW, root fresh weight; RL, root length; SA, salicylic acid; SD, stem diameter; SDW, shoot dry weight; SFW, shoot fresh weight; SL, shoot length; TCC, total chlorophyll content; TPC, total protein content; Zn, zinc.

$\left(\mathrm{T}_{2}, \mathrm{~T}_{3}, \mathrm{~T}_{4}, \mathrm{~T}_{9}, \mathrm{~T}_{10}, \mathrm{~T}_{11}\right.$ and $\left.\mathrm{T}_{12}\right)$ with higher values of the investigated attributes, whereas $T_{11}$ and $T_{12}$ were in same sub-cluster, while $\mathrm{T}_{2}, \mathrm{~T}_{3}, \mathrm{~T}_{4}, \mathrm{~T}_{9}$ and $\mathrm{T}_{10}$ in other sub-cluster. However, cluster II separated $T_{1}$ from $T_{5}$, $\mathrm{T}_{6}, \mathrm{~T}_{7}$ and $\mathrm{T}_{8}$ in sub-clusters based on the difference of morpho-physiological traits (Figure 3). 


\section{DISCUSSION}

C. argentea var. cristata is an economically important cut flower crop and its demand has increased worldwide due to its better vase life. In Pakistan, Celosia is a neglected crop and its cultivation is limited to few areas due to availability of some hybrid land racers (Miano et al., 2017). Foliar application of micronutrients like $\mathrm{Zn}$ and natural hormones like SA either separately or together considerably improved plant quality by increasing vegetative and reproductive growth by influencing physiological processes in the plants (Choudhary et al., 2016).

In the present study, $\mathrm{Zn}$-fertilised plants $\left(\mathrm{T}_{2}-\mathrm{T}_{4}\right)$ were taller and had higher growth and reproductive indices as compared to the control $\left(\mathrm{T}_{1}\right)$. The greater benefit was obtained with $1.5 \mathrm{ppm}\left(\mathrm{T}_{3}\right)$ and $2.5 \mathrm{ppm}\left(\mathrm{T}_{4}\right)$, where the plants' height, biomass, stem diameter, number buds and flower weight improved significantly up to $1.5-2.5$ folds possibly owing to optimal metabolism obtained by the application of required $\mathrm{Zn}$ to plants (García-López et al., 2019) and due to the balancing level of macro and micronutrients (Rahman et al., 2018). The current results were similar to the findings of many previous studies, where the foliar application of $\mathrm{Zn}$ improved plant height in flowering plants (Shah et al., 2016; Rehman et al., 2018) because of its potential to induce auxin synthesis, cell division, function in photosynthesis and carbohydrate metabolism (Khan et al., 2018; Awan et al., 2019; Shoaib et al., 2020). The improvements in vegetative growth including stem diameter likely to be responsible for more accumulation of photosynthetic materials and as recorded in current study, photosynthetic pigments improved by $30-50 \%$ with application of different $\mathrm{Zn}$ levels (0.5-2.5 ppm). Essentiality of $\mathrm{Zn}$ in metabolic rate of plant is confirmed, therefore, it is assumed that $\mathrm{Zn}$ by facilitating $\mathrm{CO}_{2}$ diffusion to the carboxylation sites in plants through carbonic anhydrase improved chlorophyll content, detoxified reactive oxygen species (ROS) and maintained rubisco structure (García-López et al., 2019). Therefore, observed improvement in plant growth by spraying of plants with $0.5-2.5 \mathrm{ppm}$ of $\mathrm{Zn}$ was due to the increase in chlorophyll content, since chlorophyll content is a bioindicator of the photosynthetic efficiency and one of the most important determinants of plant growth. Reports suggested that $\mathrm{Zn}$ stimulate bud-out growth by inducing the biosynthesis of hormones involved in the process (Zhu and Kranz, 2012). Moreover increase in number of bud might be associated with the development of adequate storage pool of $\mathrm{Zn}$ in stem nodes to redirect $\mathrm{Zn}$ effectively to the developing buds for subsequent bud-break and development of new plant organs (Xie et al., 2020).

Foliar application of SA separately was not effective at $50 \mathrm{ppm}\left(\mathrm{T}_{5}\right)$, while at $100 \mathrm{ppm}\left(\mathrm{T}_{9}\right)$, the investigated attributes were significantly greater and statistically at part with $\mathrm{T}_{2}-\mathrm{T}_{4}$. The present piece of work derives support from the work of earlier researchers, who reported increased growth, physiological and yield responses by exogenous application of SA at higher concentrations (100 and150 ppm) than at the lower ones (Ali and Mahmoud, 2013; Azoz and El-Taher, 2018). Improvement in TCC and CC could be attributed to role of SA in promoting reactions involving photosynthetic pigments, membrane integrity and Photosystem II activity, which may lead to better plant biomass and area (Nazar et al., 2015). Arfan et al. (2007) reported enhanced allocation of $\mathrm{N}$ and $\mathrm{S}$ to rubisco protein through SA application, and so increase in the availability of $\mathrm{CO}_{2}$ for rubisco protein (key enzyme in photosynthesis catalysing $\mathrm{CO}_{2}$ fixation) might be the reason for positive effect on plant growth and development. Furthermore, phenolic nature and harmonic behaviour of SA has been assigned to play an important role in stimulation in formation of bud and flowers (Zeb et al., 2017).

The combined SA or Zn foliar application significantly enhanced plant vegetative and reproductive growth indices at their higher levels $\left(\mathrm{T}_{10}-\mathrm{T}_{12}\right)$. The synergy of SA (100 ppm) with the highest applied dose of $\mathrm{Zn}$ (2.5 ppm) in $\mathrm{T}_{12}$ had resulted in the greatest vegetative and reproductive traits. El-Yazied (2011) recommended that foliar spraying with SA (100 ppm) + Zn (50 ppm) for better nutrient constituentsas well as for better yield and better fruit quality in Capsicum annuum. Sofy (2015) also reported beneficial effect of combined application of SA and Zn on growth, chemical constituents and yield quality in Triticum aestivum under different levels of irrigation interval. In line with these findings, foliar application of SA and $\mathrm{Zn}$ together may boost translocation of $Z n$ from vegetative to reproductive tissue, while increase $\mathrm{Zn}$ sink in buds. According to Xie et al. (2020), emerging vegetative bud and early meristematic development have a very strong demand for $\mathrm{Zn}$. Hence, synergistic outcomes of the SA and $\mathrm{Zn}$ may ameliorate plant's essential biochemical contents along with $\mathrm{Zn}$, which may activate different physiological processes such as stomatal regulation, chlorophyll formation and enzyme activation in plants. Nonetheless, synergy may improve vegetative growth and reproductive efficiency and the plants would be expected to be more capable for the better development of flowers (Choudhary et al., 2016).

A certain amount of ROS is always produced during the whole life of each aerobic organism during stress and development, while its levels are tightly controlled by antioxidant machinery comprising enzymes (e.g. CAT, POX and PPO) (Nafisa et al., 2020). Presently CAT activity was found to be $42-65 \%$ lower after $\mathrm{Zn}$, SA and $\mathrm{SA}+\mathrm{Zn}$ application than control group. The reduction in the CAT activity was greater with higher doses of $\mathrm{Zn}$ and with combined application of SA (100 ppm) $+\mathrm{Zn}$, which may indicate good state of plant towards flower production as compared to untreated plants. Alteration in the antioxidant system has been confirmed after application of SA or $\mathrm{Zn}$ in different plants through inhibition in the CAT activity and stimulation in POX activity to maintain redox status of the cell 
(Rao et al., 1997; Khan et al., 2018). Moreover, total protein content, activity of POX and PPO increased by $20-30 \%$ with all treatments, might show an active metabolic pool in the leaves because of high photosynthetic activity. Furthermore, high POX and PPO also revealed accumulation of phenolics, lignin and other defence-related secondary compounds in plant (Awan et al., 2019). POX activity accelerates lignin accumulation in cell wall, which not only increases mechanical strength of plant stalk, but also contributes in plant growth, tissue/organ development, resistance against lodging and variety of biotic and abiotic stresses (Pandey et al., 2017). There have been many suggestions regarding influence of PPOs on photosynthesis including its functioning as oxygen buffer reducing lipid peroxidation apart from its role in oxidation of phenols (Vaughn and Duke, 1984).

PCA and heat map are the most frequently utilised multidimensional method to classify treatment, and to identify the key variables and their pattern of correlations (Han et al., 2019; Siddique et al., 2020; Shariatipour et al., 2020). Differences between the treatments are easily evaluated by visualising the distances between the points in biplot, as a greater distance reflects a greater difference and vice versa. PCA and heat map analyses revealed $\mathrm{T}_{12}(100 \mathrm{ppm} \mathrm{SA}+2.5 \mathrm{ppm}$ $\mathrm{Zn})$ followed by $\mathrm{T}_{11}(100 \mathrm{ppm} \mathrm{SA}+1.5 \mathrm{ppm} \mathrm{Zn})$ as the optimum treatments for the better growth and reproduction of cockscomb plant. However $\mathrm{T}_{2}-\mathrm{T}_{4}$ and $\mathrm{T}_{9}$ exhibited intermediate to high values of the studied traits, while $\mathrm{T}_{5}-\mathrm{T}_{8}$ had least influence on the attributes studied. Moreover, note that weak correlation is shown by perpendicular angle between two variables, and high positive/high negative correlation is indicated by nearly parallel (antiparallel) angle between two variables (Han et al., 2019). Generally, all morpho-physiological traits excluding CAT were on the positive side of PCA, and were positively correlated with each other. However, growth attributes (length, biomass, number of buds per plant and flower weight) were clustered very closely (cluster 1: right lower side of biplot), which indicated very strong and positive interrelationship among them. The relationship among total TCC, CC and PPO (cluster 2: upper right side of biplot) was also strong, and these clustered closer to growth attributes as well. Clusters 1 and 2 were moderately and positively correlated with cluster 3 (total protein content and POX). The results showed that greater photosynthetic pigment could modify dynamics of key carbohydrate metabolism in both source to sink organ, resulting in better growth and reproductive indices. Important factors such as stronger stem, bud number and better flower density significantly contributed to greater growth efficiency and better stress resistance in Celosia (Zuck, 2015).Thus considering all the treatments, the results concluded that the foliar application of $100 \mathrm{ppm} \mathrm{SA}+2.5 \mathrm{ppm} \mathrm{Zn}$ improved morpho-physiological responses, which are responsible for improving the bud numbers and flower quality in $C$. argentea var. cristata.

\section{CONCLUSIONS}

Morpho-physiological traits of cockscomb are changed by varying the concentrations of SA and $\mathrm{Zn}$ sprayed either alone or in synergism. Bilateral combination of SA (100 ppm) and Zn (2.5 ppm) exhibited the highest growth attributes and flower weight. PCA-based biplot and heat map visualisation revealed the positive correlations between all treatments, and majority of the morpho-physiological characteristics of cockscomb are studied.

\section{ACKNOWLEDGEMENTS}

Authors highly acknowledge the services of the Institute of Agricultural Sciences, University of the Punjab, Pakistan, for the present research work.

\section{FUNDING}

Funding to carry out research work presented in the paper was provided by the University of the Punjab, Lahore, Pakistan.

\section{CONFLICT OF INTEREST}

Authors declare no conflict of interest.

\section{AUTHORS CONTRIBUTIONS}

A.S. designed experiment, analysed data statistically, prepared original draft of the manuscript and did project supervision. M.F.H.F. supervised experiment. A.S. performed experiments, collected data and applied statistical analysis. S.J. helped in writing manuscript. All authors have read and agreed to the published version of the manuscript.

\section{REFERENCES}

AbBas, J., AND IBrahim, B. A. (2014). Effect of salicylic acid in some vegetative and fruit traits of the black bean. Iraqi Journal of Agricultural Sciences, 45, 845-853.

Ahmad, M., Faiz, P., HaQ, S. I., Nawaz, A., IQbal, P., AND Ullah, Z. (2018). Foliar application of salicylic acid enhanced the production of tuberose (Polianthes tuberosa L). International Journal of Agricultural and Environmental Research, 4, 191-197.

Alaey, M., Babalar, M., Naderi, R., and Kafi, M. (2011). Effect of pre- and postharvest salicylic acid treatment on physio-chemical attributes in relation to vase-life of rose cut flowers. Postharvest Biology and Technology, 61(1), 91-94.

Ali, E. A., And Mahmoud, A. M. (2013). Effect of foliar spray by different salicylic acid and zinc concentrations on seed yield and yield components of mungbean in sandy soil. Asian Journal of Crop Science, 5, 33-40. 
Al-Mohammadi A. N., And Al-Rawi A. R. (2016). Effect of planting date, growth promoters, type of organic manure on growth and yield, and active ingredient of Datura stramonium L. Tikrit Journal for Agricultural Sciences, 16, 26-50.

Arfan, M., Athar, H. R., And Ashraf, M. (2007). Does exogenous application of salicylic acid through the rooting medium modulate growth and photosynthetic capacity in two differently adapted spring wheat cultivars under salt stress? Journal of Plant Physiology, 164(6), 685-694.

Awan, Z. A., Shoaib, A., And Khan, K. A. (2019). Crosstalk of $\mathrm{Zn}$ in combination with other fertilizers underpins interactive effects and induces resistance in tomato plant against early blight disease. The Plant Pathology Journal, 35(4), 330.

Azoz, S. N., ANd El-TAher A. M. (2018). Influence of foliar spray with salicylic acid on growth, anatomical structure and productivity of cowpea plant (Vigna unguiculata L.). Current Science International, 7, 553-564.

Basit, A., Shah, K., Rahman, M. U., Xing, L., Zuo, X., Han, M., And Khalid, M. A. (2018). Salicylic acid an emerging growth and flower inducing hormone in marigold (Tagetes sp. L.). Pure and Applied Biology, 7, 1301-1308.

Bhatt, R., Hossain, A., and Sharma, P. (2020). Zinc biofortification as an innovative technology to alleviate the zinc deficiency in human health: A review. Open Agriculture, 5(1), 176-186.

Cabot, C., Martos, S., Llugany, M., Gallego, B., Tolrà, R., And Poschenrieder, C. (2019). A role for zinc in plant defense against pathogens and herbivores. Frontier in Plant Sciences, 10, 1171, doi: 10.3389/ fpls.2019.01171.

Choudhary, A., Mishra, A., Bola, P. K., Moond, S. K., And Dhayal, M. (2016). Effect of foliar application of zinc and salicylic acid on growth, flowering and chemical constitute of African marigold cv. Pusa narangi gainda (Targets erecta L.). Journal of Applied and Natural Science, 8, 1467-1470.

Dempsey, D. M., and Klessig, D. F. (2017). How does the multifaceted plant hormone salicylic acid combat disease in plants and are similar mechanisms utilized in humans? BMC Biology, 15, doi: 10.1186/s12915017-0364-8.

EL-YAZEID, A. A. (2011). Effect of foliar application of salicylic acid and chelated zinc on growth and productivity of sweet pepper (Capsicum annuum L.) under autumn planting. Research Journal of Agriculture and Biological Sciences, 7, 423-433.

García-López, J. I., Niño-Medina, G., Olivares-SÁenZ, E., Lira-Saldivar, R. H., Barriga-Castro, E. D., Vázquez-Alvarado, R., Rodríguez-Salinas, P. A., And Zavala-GarcíA, F. (2019). Foliar application of zinc oxide nanoparticles and zinc sulfate boosts the content of bioactive compounds in habanero peppers. Plants, 8(8), 254, doi: 10.3390/plants8080254.
Han, L., YAnG, G., DAi, H., YAnG, H., Xu, B., Li, H., Long, H., Li, Z., Yang, X., And ZhaO, C. (2019). Combining self-organizing maps and biplot analysis to preselect maize phenotypic components based on UAV high-throughput phenotyping platform. Plant Methods, 15, 57, doi: 10.1186/s13007-019-0444-6.

Hasanuzzaman, M., Nahar, K., Anee, T. I., and Fujita, M. (2017). Glutathione in plants: Biosynthesis and physiological role in environmental stress tolerance. Physiology and Molecular Biology of Plants, 23, 249-268.

Hembrom, R., Singh, A. K., Sisodia, A., Singh, J., And Asmita. (2015). Influence of foliar application of iron and zinc on growth, corm and cormel yield in gladiolus cv. American Beauty. Environment and Ecology, 33(4), 1544-1546.

JANDA, T., Gondor, O. K., Yordanova, R., Szalai, G., AND PÁL, M. (2014). Salicylic acid and photosynthesis: Signalling and effects. Acta Physiologiae Plantarum, 36(10), 537-546.

Khan, K. A., Shoaib, A., Awan, Z. A., Basit, A., And Hussain, M. (2018). Macrophomina phaseolina alters the biochemical pathway in Vigna radiata chastened by $\mathrm{Zn}^{2+}$ and FYM to improve plant growth. Journal of Plant Interactions, 3(1), 131-140.

KHAN, N., BANO, A. M., AND BABAR, A. (2020). Impacts of plant growth promoters and plant growth regulators on rainfed agriculture. PLOS ONE, 15, e0231426, doi: 10.1371/journal.pone.0231426.

Kieft-Pro Seeds. (2010). Grower Facts: Bombay Celosia. Ball Horticultural Company.

Kolade, O., Harp, A., Jones, C., and Lopez, J. (2018). Effects of zinc fertilization on growth and leaf nutrient content of Celosia argentea L. Journal of Applied Horticulture, 20(3), 202-206.

LeunG, w. T. W. (1968). Food composition table for use in Africa. US Department of Health, Education, and Welfare, Public Health Service, Health Services and Mental Health Admin., National Center for Chronic Disease Control Nutrition Program.

Luhová, L., Lebeda, A., Kutrová, E., Hedererová, D., And PeČ, P. (2006). Peroxidase, catalase, amine oxidase and acid phosphatase activities in Pisum sativum during infection with Fusarium oxysporum and F. Solani. Biologia Plantarum, 50(4), 675-682.

Mastuti, R., Arumingtyas, E. L., and Fatinah, A. A. (2015). Genetic diversity of celosia variants in east java based on polyphenol oxidase-PPO genes. Procedia Chemistry, 14, 361-366.

Matysiak, K. (2020). Effect of foliar applied acetylsalicilic acid on wheat (Triticum aestivum L.) under field conditions. Agronomy, 10(12), 1918, doi: 10.3390/agronomy10121918.

Miano, T. F., Baloch, A. U. R., Buriro, M., Miano, A., And Miano, T. F. (2017). Vegetative growth and flowering behavior of cockscomb (Celosia cristata L.) in response to sowing dates. Journal of Horticulture, 4, 2-4. 
Miura, K., AND TADA, Y. (2014). Regulation of water, salinity, and cold stress responses by salicylic acid. Frontier in Plant Sciences, 5, 4, doi: 10.3389/ fpls.2014.00004.

Nafisa, Shoaib, A., Iqbal, J., And Khan, K. A. (2020). Evaluation of phenotypic, physiological and biochemical attributes connected with resistance in tomato against Alternaria. Acta Physiologiae Plantarum, 42, 88, doi: 10.1007/s11738-020-03076-2.

NAZAR, R., UMAR, S., AND KHAN, N. A. (2015). Exogenous salicylic acid improves photosynthesis and growth through increase in ascorbate-glutathione metabolism and s assimilation in mustard under salt stress. Plant Signaling \& Behavior, 10, e1003751, doi: 10.1080/15592324.2014.1003751.

Pacheco, A. C., Cabral, C., Fermino, E. S. S., and Aleman, C. C. (2013). Salicylic acid-induced changes to growth, flowering and flavonoids production in marigold plants. Journal of Medicinal Plant Research, 1, 95-100.

PaL, V., AND Kumar, M. R. (2015). Effect of various levels of spacing and salicylic acid treatment on vegetative growth and flowering of gladiolus (Gladiolus grandiflora L.) cv. White prosperity. South Asian Journal of Food Technology and Environment, 1, 101-104.

Pandey, V. P., Awasthi, M., Singh, S., Tiwari, S., And Dwivedi, U. N. (2017). A comprehensive review on function and application of plant peroxidases. Biochemistry and Analytical Biochemistry, 6(308), $1-16$.

Pérez, C. D. P., Pozza, E. A., And Pozza, A. A. A. (2020). Boron, zinc and manganese suppress rust on coffee plants grown in a nutrient solution. European Journal of Plant Pathology, 156, 727-738.

Rahman, M., Islam, M., Sheikh, M., Hossain, M., Kawochar, M., And Alam, M. (2018). Effect of foliar application of zinc on the yield, quality and storability of potato in Tista meander floodplain soil. Pertanika Journal of Tropical Agricultural Science, 41, 1779-1793.

Rao, M. V., Paliyath, G., Ormond, P., Murr, D. P., And Watkin, C. B. (1997). Influence of salicylic acid on $\mathrm{H}_{2} \mathrm{O}_{2}$ production, oxidative stress and $\mathrm{H}_{2} \mathrm{O}_{2}$ metabolizing enzymes. Plant Physiology, 115, 137-149.

Rehman, A., Farooq, M., Ozturk, L., Asif, M., And Siddique, K. H. M. (2018). Zinc nutrition in wheatbased cropping systems. Plant and Soil, 422, 283315.

Shah, S. T., Ullah, S., Khan, N., Sajid, M., Rab, A., Amin, N. U., and Rahman, S. (2016). Effect of zinc as a foliar spray on growth and flower production of marigold (Tagetes erecta L.). Pure and Applied Biology, 5, 738-743.

Shaheen, R., Hassan, I., Hafiz, I. A., Jilani, G., And AbBasi, N. A. (2015). Balanced zinc nutrition enhances the antioxidative activities in Oriental lily cut-flower leading to improved growth and vase quality. Scientia Horticulturae, 197, 644-649.

Shariatipour, N., Alavikia, S., Moghaddam, M., Velu, G., AND Heidari, B. (2020). Foliar applied zinc increases yield, zinc concentration and germination in wheat genotypes. Agronomy Journal, 112(2), 961-974.

Shodib, A., Ali, H., Javaid, A., And Awan, Z. A. (2020). Contending charcoal rot disease of mungbean by employing biocontrol Ochrobactrum ciceri and zinc. Physiology and Molecular Biology of Plants, 26, 1385-1397.

Siddique, S., Shoaib, A., Khan, S. N., And Mohy-Ud-Din, A. (2020). Screening and histopathological characterization of sunflower germplasm for resistance to Macrophomina phaseolina. Mycologia, 113(1), 92-107. doi: 10.1080/00275514.2020.1810516

Singh, A. K., Anjana, S, Vandana, S., and Abha, K. (2018). Effect of foliar application of boron and zinc on growth and flowering characters in African marigold cv. And flowering characters in African marigold. Journal of Ornamental Horticulture, 21, $1-6$.

Singh, A. K., Hembrom, R., Sisodia, A., And Asmita, A. K. P. (2015). Effect of iron and zinc on flowering and postharvest life in gladiolus (Gladiolus spp.). Indian Journal of Agricultural Sciences, 86, 1316-1319.

Sofy, M. R. (2015). Application of salicylic acid and zinc improves wheat yield through physiological processes under different levels of irrigation intervals. International Journal of Plant Research, $5,136-156$.

Surse, S. N., Shrivastava, B., Sharma, P., Sharma, J., And GIDE, P. S. (2014). Pharmacognostic standardisation of whole plant of Celosia argentea var. cristata (L). International Journal for Pharmaceutical Research Scholars, 3(1-3), 387-392.

Tahjib-Ul-Arif, M., Siddiqui, M. N., Sohag, A. A., Sakil, M. A., Rahman, M. M., Polash, M. A., Mostofa, M. G., and Tran, I. S. (2018). Salicylic acid-mediated enhancement of photosynthesis attributes and antioxidant capacity contributes to yield improvement of maize plants under salt stress. Journal of Plant Growth Regulation, 37(4), 1318-1330.

TANG, Y., Xin, H. I., AND Guo, M. I. (2016). Review on research of the phytochemistry and pharmacological activities of Celosia argentea. Revista Brasileira de Farmacognosia, 26, 787-796.

Vaughn, K. C., And Duke, S. O. (1984). Function of polyphenol oxidase in higher plants. Physiologia Plantarum, 60, 106-112.

Xie, R., Zhao, J., Lu, L., Brown, P., Lin, X., Webb, S. M., Ge, J., Antipova, O., Li, L., And Tian, S. (2020). Seasonal zinc storage and a strategy for its use in buds of fruit trees. Plant Physiology, 83, 1200-1212. 
YAng, T. P., And Poovaiah, B. W. (2002). Hydrogen peroxide homeostasis: Activation of plant catalase by calcium/calmodulin. Proceedings of the National Academy of Sciences, 99(6), 4097-4102.

Zeb, A., Fazal Ullah, E., Gul, S. E., Khan, M., Zainub, B., Khan, M. N., AND Noor Ul Amin (2017). Influence of salicylic acid on growth and flowering of zinnia cultivars. Science International, 29(6), 1329-1335.
ZhU, H., AND KranZ, R. G. (2012). A nitrogen-regulated glutamine amidotransferase (GAT1 2.1) represses shoot branching in Arabidopsis. Plant Physiology, 160, 1770-1780.

Zuck, C. (2015). Reformation of specialty cut flower production for Celosia cristata. University of Minnesota (Landscape Design and Planning, Department of Landscape Architecture).

Received: December 24, 2020; accepted: March 1, 2021 